\title{
The Impacts of Post-task Activities on Iranian EFL Learners’ Reading Achievements
}

\author{
Marzieh Khademi \\ Department of English, Baqir al-Olum University, Qom, Iran \\ Morteza Mellati \\ Department of English, Tehran University, Tehran, Iran \\ Samaneh Notghi Moghaddam \\ Al-Mustafa Open University, Qom, Iran
}

\begin{abstract}
As learners' proficiency is more important than their abstract knowledge of the language rules, Task-Based Language Teaching (TBLT) is of crucial values today. Task-based instruction has three phases: pre-task, during-task, and post-task. Studies have demonstrated that all of them might play a significant role in language teaching. Moreover, recent studies have compared different tasks over time. However, it is still unclear how different phases of a task impact learners' language ability. To better understand this issue, this particular study investigated the effect of post-task activities on EFL learners' reading achievements. To conduct the study, 47 Iranian EFL learners in a private language institute in Esfahan, Iran were selected. The participants were assigned into three groups randomly (two experimental groups and one control group). Through ten sessions (five weeks), the participants learned how to focus on post-task activities such as reflection on the task and repeated performance in a task-based instruction. The required data were collected through pretest, posttest, and semi-structured interview. After the course, semi-structured interviews were also conducted with five students from experimental groups. The results of both quantitative and qualitative data indicated that post-task activities have a significant effect on learners' language proficiency, their reading achievements, and their motivation to participate in classroom tasks. The implementation and discussions were also discussed.
\end{abstract}

Index Terms — task-based language teaching, post-task activities, reading achievements, repeated performance

\section{INTRODUCTION}

The notion of Task-Based Language Teaching (TBLT) has recently become a widespread approach in many educational contexts (Ma \& Kelly, 2006; Shintani, 2011; Wang, 2012). However, the notion has received a status of orthodoxy since stakeholders and curriculum leaders prescribe teachers in worldwide language settings how they should teach, and approximately all publishers are describing their new textbooks and materials as task-based; therefore, defining TBLT clearly is an effective action (Littlewood, 2007). There has also been a permanent augment in the number of studies in which tasks and task-based education are the fundamental parts of learning process (Ellis, 2009). TBLT has drawn generally on research into second language acquisition. TBLT considers task as the fundamental unit which teachers and curriculum designers design their lesson and content just based on it. In addition to all the uniqueness characteristics that a task should have such as meaning, gap, need for learners' resources, etc, it should be clearly distinguished from other types of classroom activities such as situational grammar exercises (Laufer \& Hulstijn, 2001; Ajideh, 2003; Mcdonough \& Chaikitmongkol, 2007; Lee, 2011; Motallebzadeh \& Ganjali, 2011; Huang, Eslami, \& Willson, 2012).

Ellis (2009) stated that in every task-based education three issues should be considered clearly. The issues are the kinds of tasks which teachers include in a language course, the content of those tasks, and finally the way of sequencing the tasks to facilitate language learning. He also states that in addition to those three issues methodological points which consider how to structure a task-based lesson and what type of participatory structure to employ should be defined clearly in the early phases of task-based instruction. A task-based lesson or a task-based instruction according to Ellis (2009) has three phases (pre-task phase, main task phase/during task, and post-task phase). There are different modes for the performance-based on the types of tasks and phases. Tasks can be performed in a whole-class context, in pairs, in groups, or by learners working individually (as cited in Khodabakhshzadeh \& Mousavi, 2012).

Previous studies mostly emphasized during phase in their studies (Ajideh, 2003; Derwing et al., 2004; Finch, 2006; Huang et al., 2012; Brabander \& Martens, 2014; Lynch \& McLean, 2001; García Mayo, 2007; Samuda and Bygate, 2008). Other phases of task-based instruction have been ignored in the literature; therefore, the present study aimed to attract the attention of teachers and stakeholders towards the crucial role that other phases especially post-task phase. According to Ellis (2009) post-task phase provides an interesting opportunity for a repeated performance encourages 
reflection on how the task was performed and encourages attention to form in particular to those forms that proved problematic to the learners when they performed the task. The assumption underlying this study is generally the effect of the application of the second language teaching theories and specifically the Task Based Language Teaching (TBLT) theories on second language learning. This theory is mostly based on the application of whatever is the facilitating, effective, and situationally appropriate in second language teaching and learning. In fact, one can trace the roots of these types of task-based language teaching methods in second language learning theories and the researches done in this realm. Designing and applying a task-based instruction needs special attention to the process through which the task is considered pivotal. Although there are diverse ideas (Littlewood, 2007; Ellis, 2009; Shintani, 2011; Lee, 2011, Mellati, Khademi, \& Etela, 2015) concerning the steps and procedures, the consensus about the three main steps cannot be ignored.

The first phase of this task-based instruction is the pre-task. This phase includes all types of activities that the teacher and learners do before getting involved in the main task. The main purpose of pre-phase is preparing second language learners to do the task in a way which promotes their acquisition (Ellis, 2009). According to Lee (2011) a pre-task activity provides what second language learners will be required to perform and the nature of the outcome they have in their minds. The second phase is the during-task activities. In this phase the teacher decides about the activities needed to perform the task. Ellis (2009) believes that the methodological options underlying this phase are of two basic kinds: first, 'task performance options' and second, 'process options'. The third phase according to Ellis (2009) is the post-task phase or post-task activities through which we can accomplish three main goals. Firstly, a post-task activity offers an appropriate opportunity to repeat a task; secondly, it encourages learners to reflect on how the task was performed; and finally, it fosters attention to form, it means that as a feedback to learners' performance has paid especial attention to problematic parts of the task that learners have performed.

This study is to focus the vital role of the post-task activities in learning the second language. Traditionally it is believed that the first two phases of the task-based activities play a significant role in learning while according to Ellis (2009) the third phase can be more important in this regard. Repeating what learners have learnt in the first and second phases and specifically different methods of this performance are appropriate strategies for intensifying and internalizing what learners have learnt in the first two phases; therefore, this study investigated the impacts of post-task activities on the Iranian EFL learners' reading achievements.

\section{REVIEW OF LITERATURE}

One of the major developments during the last decade was different task-based approaches to instruction. There were mainly two approaches namely strong and weak versions (Skehan, 2009). The advocates of the first approach proposed that tasks are not the driving force for syllabus design and it cannot specify a particular educational instruction. Those in favor of the second approach, however, considered the emergent of acquisitional process as central. In this approach the task is the center of attention in both teaching and learning theories. Bygate, Skehan, and Swain (2001) stated that a task is an activity that involves learners to use language to attain a desired goal. Tasks have been considered as the organizing unit of learning in many studies recently done by researchers (Bygate et al., 2001; Stylianides and Stylianides, 2008; Ellis, 2009; Van den Branden, Bygate, and Norris, 2009).

In spite of quite a few differences and various approaches, all teachers and researchers have some common goals in conducting a task-based instruction. All of them mostly focused on communicative language ability rather than focused on form or grammar ability (Nunan, 2006). It is, henceforth, the Nunan's (2006) definition of task that this paper refers to that term: A task is a classroom activity that engages learners in processes such as comprehending, manipulating, producing or interacting in the target language. Learners' attention is on manipulating or monitoring their grammatical knowledge to express their intended meaning. A task in this definition should also have some fundamental characteristics such as a sense of completeness, a goal, and a communicative act with a beginning, middle and end. Ellis (2009) sets some criteria for a classroom activity to be considered as a task. He stated that the principal focus of that activity should be on meaning. Every task should have some kinds of gap; it means that learners have to convey information, or express their opinions through a task. Second language learners should use their own language knowledge and ability to perform a task or activity. These abilities and skills can be linguistic or non-linguistic. The final and the most important characteristic of a task is that every task should have a clearly defined outcome. This outcome should be non-linguistics. Learners use their language knowledge as a medium to reach the outcome. Widdowson (2003) however, argued that the criteria to define a task are formulated loosely. They cannot differentiate tasks from other classroom activities. Ellis (2009) supports Widdowson's (2003) idea and stated that he is right to point out that for example in Skehan's (2009) criteria it is not clarified whether the meaning which is the primary criterion is semantic or pragmatic. In other words, it is hard to distinguish classroom tasks from other kinds of classroom activities. However, Ellis (2009) mentioned that Widdowson (2003) overlooked the point that the goal of task definitions are not to specify their learning outcomes. They just focused on the kind of instructional activity that a task covers. The result of such challenges was the notion of Task-Based Language Teaching (TBLT).

The concept of TBLT was first established by Prabhu (1987). He stated that this notion focused mainly on communication rather than grammar teaching and language form. The major goal of a task in the TBLT is negotiating meaning to perform a particular activity (Samuda and Bygate, 2008; Khodabakhshzadeh \& Mousavi, 2012). In TBLT, 
language learning occurs when learners doing some classroom activities which have goals and need to be completed. Teachers and curriculum designers try to focus on non-linguistics functions. Learners should use language as a tool to obviate their real needs in the context. Authenticity is one of the major features of task-based instruction. When learners complete a task, they use language in the real-world context (Lynch and McLean, 2001). There is no pre-selected language need or syllabus in TBLT. Teachers manipulate tasks as facilitators and try to cover learners' needs and interest and to meet the demands of the activities and tasks (Nikula, 2015). The primary driving force in this approach is motivation for communication; therefore, even unlimited knowledge about language is useless and inapplicable. The only applicable knowledge is a knowledge which language learners use in their classroom and out of classroom communications. Another influenced factor that got a lot of attention is exposure to the authentic target language which occurs only in a naturally occurring context. This means that, authentic and unleveled materials are more appropriate than educational materials that are designed especially for the language classroom (Littlewood, 2007; Llinares and Dalton-Puffer, 2015). Exposure to authentic sources will lead into language proficiency. Learners would be able to communicate in target language proficiently. TBLT and task-based instruction can provide adequate environment for delivering authentic sources (educational tasks) as well as authentic language use in the classroom that eventuate in learners' language proficiency. Researchers believed that an effective task-based instruction improve proficiency and language ability of second or foreign language learners (Derwing, Rossiter, and Thomson, 2004; Schmitt and Carter, 2004; Skehan, 2009; Shintani, 2011; Brabander and Martens, 2014).

One of the main challenging concerns for English language teachers is improving the learners' proficiency. Finding appropriate and convenient ways to facilitate language learning and support language learners to improve their proficiency level. This is significantly challenging problem especially in countries where learners share a common first language and have little or no exposure to the second or foreign language outside the classroom. Lyster (2014) claimed that pair and group work communication tasks or task-based instructions are mostly unproductive or not as efficient as teachers expect. The reason of this phenomenon is very simple. The problem is that language learners performed these tasks mostly in their native language. Learners are eager to express their ideas in English; however, not only it is pretty hard for them to do it, but also they do not have skillful teachers that can convince them. Mozgalina's (2015) solution to this problem is focusing exclusively on proficiency and making learners communicate with English only. He also added that the only outcome of the years is an extensive knowledge of grammar and vocabulary that teachers cannot put them into practice (as cited in Khodabakhshzadeh \& Mousavi, 2012). Many teachers and researchers believe that task-based instruction is the most prominent language teaching strategy to improve language learners' proficiency level. When they utilize this proficiency-enhancing strategy or educational framework, second language learners would get enough practice from task-based course (Nikula, 2015; Khademi, Mellati, and Etela, 2014; Hei, Strijbos, Sjoer, and Admiraal, 2016). Nikula (2015) have focused on super segmental elements with proficiency practice. In this study, classroom activities such as repetition, the proper use of discourse markers, prosodic cues and cohesive links are chosen as posttask activities.

Llinares and Dalton-Puffer (2015) stated that in countries where learners have a common first language, finding techniques to help learners improve their language proficiency is an important factor. They believe that task-based instruction was very effective in encouraging Japanese to improve their language proficiency, even in large classrooms (Ellis, 2001; Nation, 2001; Lewis, 2002; Kim and Tracy-Ventura, 2013; Sadeghi and Sharifi, 2013; Bao, 2015). In other words, by delivering classroom tasks teachers forced learners to be creative and use their own ability and strategies in completing educational tasks.

Numerous studies in the literature have focused on task-based instruction and the impacts of task on different aspects of language teaching and learning. Ruiz-Funes (2015) investigated the effect of task complexity and to reexamine the relationship between task complexity and linguistic output on the level of language proficiency and performance on task of the learners. The results indicated that there is an effective interaction between task complexity, linguistic output, and language proficiency. Asgarikia (2014) explored the effects of task type, strategic planning and no planning on written performance of Iranian intermediate EFL learners and found that giving students enough time to plan before starting the task, leading them to a better performance. Also, the type of the task had a significant effect on their performance; for instance, the structured tasks were easier to perform than the other tasks. Geng and Ferguson (2013) investigated the influence of task type and participatory structure (or classroom organization) in pre-task on the fluency, complexity and accuracy of students' speaking ability. The obtained results indicated that teacher-led planning had some excellent benefits for accuracy, and individual planning for complexity, however, neither of them are meaningful and significant. Najjari (2014) have explored theoretical and practical considerations of implementation of TBLT in Iran and found that implementing TBLT in Iran is possible if teachers follow valid textbooks and communicative-oriented activities. Bagher Shabani and Ghasemi (2014) have investigated the effect of TBLT and Content-Based Language Teaching (CBLT) on the Iranian intermediate ESP students' reading comprehension ability. The study was conducted with 60 participants that were assigned into two groups: a control group (CBLT) and an experimental group (TBLT). The findings indicated that TBLT has been more effective than CBLT in teaching reading comprehension to Iranian ESP students. However there are a lot of studies have conducted on the effect of different types of task and task-based instruction in the literature, there is no study that investigated the impacts of post-task activities on EFL learners' 
language proficiency. Therefore, the current study investigated the impacts of task-based instruction and post-task activities on the Iranian EFL learners' reading achievements.

Research Question

Do task-based instruction and post-task activities such as repeated performance and asking personal questions have any significant effects on Iranian intermediate EFL learners' reading achievements?

\section{METHODOLOGY}

\section{A. Participants}

A total number of 47 intermediate EFL learners from 62 participants were randomly assigned in to three groups after taking the Oxford Placement Test (OPT). All participants showed interest to take part in this study. Group A consisted of 15 learners, group B consisted of 15, and group C consisted of 17 learners. Group C was the control group. Participants' ages range from 18 to 23 years. All of them were intermediate EFL male learners at a private language institute in Esfahan, Iran.

\section{B. Instrumentations and Materials}

To conduct the present study, the following materials and instruments were employed:

Oxford Placement Test. OPT is a standardized language proficiency test (a version of OPT that is called Solutions Placement Test) that was administered to determine homogenous learners. The test contained 50 multiple choice questions and also included a reading text with 10 graded comprehension questions (five true-false and five multiple choice items). Based on the institute's placement test, all participants were in intermediate level. However, to ensure that all of them were in the same proficiency level OPT was administered.

Michigan English Language Assessment Battery. University of Michigan developed a standardized test to evaluate reading competence of adult non-native speakers of English. This test battery consists of three parts including written composition, listening comprehension, and grammar, cloze, vocabulary and reading comprehension multiple-choice questions, and also one optional speaking test in the form of a one-on-one interview with an examiner. In the current study, reading comprehension part of MELAB (1997) test was administered to the participants to determine the students' reading comprehension competence. This test included four reading passages with total 20 multiple-choice reading comprehension questions for students to be answered in 30 minutes. This test was employed as pretest in the current study. Since one part of this test was employed in the present study, it was piloted with 20 learners of similar test-takers at the Science Innovators Language Institute in Esfahan, Iran. Cronbach's Alpha formula for multiple choice items was employed and the results showed a reliability index of .764 ( $\mathrm{r}=.764)$.

Reading posttest. A reading posttest was developed from Select Reading Textbook by the researcher to determine the learners' reading comprehension competence at the end of research and after treatment. This researcher-made coursebased test contained 20 items; four reading passages followed by five multiple choice questions similar to the content of the reading text book. This test was piloted with 20 learners of similar test-takers at the Science Innovators Language Institute in Esfahan, Iran. Cronbach's Alpha formula for multiple choice items was employed; the results showed a reliability index of $.808(\mathrm{r}=.808)$.

Semi-structured interview. The researchers conducted semi-structured interviews with five participants to investigate in-depth information about conducting post-task activities in the classroom. In these face-to-face interviews that were conducted in 30 minutes, the researchers began with lines of questioning and allowed the participants to address other related topics if they liked. The lines of questioning were as follows: Attitudes toward task-based instruction; benefits of employing task-based instruction and post-task activities in language teaching contexts; challenges of conducting such a program; and learners' motivation about participating in such language environments.

Select readings: Intermediate. This reading textbook (Second Edition) (Lee \& Gunderson, 2011) is a teacherapproved American English reading textbook series for intermediate and university students. It contained a range of high interest reading texts approved by American experienced teachers. This four-level American English reading course uses carefully selected reading texts to assist learners to read more effectively. Exercises before and after reading practice reading skills, check comprehension and build vocabulary. This textbook has some special features that are suitable for this study.

\section{Procedures}

To ensure the homogeneity of the participants at the outset of the study, OPT was administered to 62 intermediate female EFL learners studying at a private English Language Institute in Esfahan, Iran. Having analyzed the data, 47 participants were chosen for the purpose of this study. Then, the selected participants were randomly assigned to three groups (two experimental groups and one control group). They were taught by three different teachers. To find out the effect of treatment (the effects of post-task activities such as asking comprehension questions, repeated performance, and analyzing and noticing the form or reflecting on the task) participants' reading comprehension was evaluated at the beginning of the study; therefore, the participants in three groups were asked to answer the MELAB at the outset of the study. During 10 sessions (two sessions per week and every session lasted one hour and half) of the treatment, participants in the experimental groups were exposed to task-based instruction and particularly post-task phase and 
post-task reading activities. The material of the study was Select Readings Intermediate textbook. The participants were randomly assigned to three groups.

In groups A and B, learners received reading tasks and the teacher activated learners' background knowledge by asking them questions about their opinions and linking the key concepts through comprehension questions. In these groups, the teachers proposed questions of the learners that encourage the skill of metacognition and allow learners to ask their own questions. A regulatory checklist is a list of questions learners need to ask themselves during a problem solving task. This helps the learners arrange, monitor and evaluate their own learning by using a series of questions. Reflection on their learning is one of the important post-task activities. In this study, reflection on their learning was conducted through journaling. Journaling about their thinking help learners monitor their own understanding by giving them the opportunity to question the content, summarize key concepts, make predictions and connect it to prior knowledge. With the incorporation of concept maps, regulatory checklists and journaling, teachers can develop the metacognitive thinking in their classrooms. In this way learners can take control of and monitor their own learning. Learners can undergo greater conceptual changes and retain the information longer. In the last phase of task-based instruction which was the main concern of this study was, learners repeated their performance but in different forms. A watchful repeated performance shed light on learners' strengths and weaknesses. Consequently, learners can reflect on their performance and review their learning process. Repeated performances and some sort of self-monitoring and selfreflection were the central actions of learners in the two experimental groups. In group C (control group), just like the conventional reading class, the teacher read the passages and wrote the synonyms and antonyms of new vocabularies and the board. After the teaching, the learners can ask their questions if any.

During the pretesting, attention was devoted to the length of time should be allowed for work on each of the problems or topics selected for use (most appropriate time that learners can perform their tasks). What was wanted was a span of time long enough so that members of the groups would have adequate opportunity to express all the ideas which occurred to them within the working period. At the same time, the time period should be short enough in a way that individuals would not become bored by being forced to continue to solve a problem long after they had essentially exhausted their opinions and ideas. A thirty-minute time period was finally selected as the most appropriate time in which would permit learners to express all ideas to solve their classroom problems. In addition, this time period would not result in excessive periods of silence for language learners (Taylor, Berry, and Block, 1958).

Finally, the groups took a reading comprehension posttest in order to check and compare their reading comprehension achievement. The participants of three groups took the post-test at the very last session of their intensive reading course. Data were collected for further statistical analyses. The final results were compared within and between groups employing statistical techniques. After the course, the researchers conducted semi-structured interviews with five participants from experimental groups to investigate in-depth information about conducting post-task reading activities in the classroom. In these face-to-face interviews that were conducted in 30 minutes, the researchers began with lines of questioning and allowed the participants to address other related topics if they liked. The lines of questioning were as follows: Attitudes toward task-based instruction; benefits of employing task-based instruction in language teaching context; challenges of conducting such a program; and learners' motivation about participating in such language environments.

\section{RESULTS AND DisCUSSIONS}

\section{A. Quantitative Data Analysis}

In order to classify them in almost homogenized groups and elicit the required number of participants for the purpose of the study, they were given the Oxford Placement Test (OPT) to determine their levels of proficiency in English. After scoring the papers, those who scored one standard deviation above and below the mean (i.e., mean \pm 1 ) were selected for the main part of the study. To ensure the homogeneity of the participants, those who get the score between 30-47 from the total score of 60 in OPT were selected as the intermediate level for main participants of the study. In other words, 47 learners got the scores 30-47, therefore, the total number of participants in the main study was 47 ( $N=47$ ). And those 15 students who got the score below 35 were excluded from the study because they were regarded as heterogeneous.

In many research situations, however, researchers are interested in comparing the mean scores of more than two groups. In this situation, they would use analysis of variance (ANOVA). Having collected the results of reading part of MELAB in the pretest, the researcher analyzed the data employing One-way Analysis of Variance (ANOVA). The purpose of this analysis was to estimate the participants' level of reading comprehension before the study began.

TABLE I.

DESCRIPTIVE STATISTICS FOR PRETEST

\begin{tabular}{|c|c|c|c|c|c|c|c|c|}
\hline & \multirow{2}{*}{$\mathrm{N}$} & \multirow{2}{*}{ Mean } & \multirow{2}{*}{ Std. Deviation } & \multirow{2}{*}{ Std. Error } & \multicolumn{2}{|c|}{$95 \%$ Confidence Interval for Mean } & \multirow{2}{*}{ Min } & \multirow{2}{*}{$\operatorname{Max}$} \\
\hline & & & & & Lower Bound & Upper Bound & & \\
\hline Group A & 15 & 12.87 & 1.922 & .496 & 11.80 & 13.93 & 9 & 16 \\
\hline Group B & 15 & 12.93 & 1.870 & .483 & 11.90 & 13.97 & 8 & 16 \\
\hline Group C & 17 & 12.35 & 1.656 & .402 & 11.50 & 13.20 & 10 & 15 \\
\hline Total & 47 & 12.70 & 1.793 & .261 & 12.18 & 13.23 & 8 & 16 \\
\hline
\end{tabular}


As the results in TABLE I show, mean and standard deviation of three groups are $(\mathrm{M}=12.87, \mathrm{SD}=1.922)$ for group $\mathrm{A}$ $(\mathrm{M}=12.93, \mathrm{SD}=1.870)$ for group $\mathrm{B}$, and $(\mathrm{M}=12.35, \mathrm{SD}=1.656)$ for group $\mathrm{C}$ respectively. The results do not show much difference between the three groups in their general level of reading comprehension at the outset of the study. Meanwhile, to ensure true homogeneity of the participants' reading comprehension competency ( $N=47)$, One-way Analysis of Variance (ANOVA) was conducted.

TABLE II.

RESULTS OF ANOVA FOR PRETEST

\begin{tabular}{l|l|l|l|l|l}
\multicolumn{1}{l}{ ANOVA } & Sum of Squares & df & Mean Square & F & .499 \\
\hline Between Groups & 3.281 & 2 & 1.640 & & \\
Within Groups & 144.549 & 44 & 3.285 & & \\
Total & 147.830 & 46 & & \\
\hline
\end{tabular}

A one way between-groups analysis of variance was conducted to explore the reading comprehension competency of participants as measured by MELAB. The participants were divided into three groups randomly. There was no statistically significant difference at the $p<.05$ level in MELAB scores for the three groups: $F(2,44)=.499, p=.610$. The results of one way ANOVA showed that there is no significant difference between three groups at the outset of the study.

To determine the effects of treatment that was the effect of post-task activities on EFL learners' achievement, the researchers employed one way ANOVA.

TABLE III.

DESCRIPTIVE STATISTICS FOR POSTTEST

\begin{tabular}{|c|c|c|c|c|c|c|c|c|}
\hline & \multirow[t]{2}{*}{$\mathrm{N}$} & \multirow[t]{2}{*}{ Mean } & \multirow[t]{2}{*}{ Std. Deviation } & \multirow[t]{2}{*}{ Std. Error } & \multicolumn{2}{|c|}{ 95\% Confidence Interval for Mean } & \multirow[t]{2}{*}{ Minimum } & \multirow[t]{2}{*}{ Maximum } \\
\hline & & & & & Lower Bound & Upper Bound & & \\
\hline Group A & 15 & 14.87 & 1.506 & .389 & 14.03 & 15.70 & 12 & 18 \\
\hline Group B & 15 & 16.73 & 1.831 & .473 & 15.72 & 17.75 & 13 & 20 \\
\hline Group C & 17 & 13.18 & 1.185 & .287 & 12.57 & 13.79 & 11 & 15 \\
\hline Total & 47 & 14.85 & 2.095 & .306 & 14.24 & 15.47 & 11 & 20 \\
\hline
\end{tabular}

As the results in TABLE III show, mean and standard deviation of three groups are $(\mathrm{M}=14.87, \mathrm{SD}=1.506)$ for group $\mathrm{A},(\mathrm{M}=16.73, \mathrm{SD}=1.831)$ for group $\mathrm{B}$, and $(\mathrm{M}=13.18, \mathrm{SD}=1.185)$ for group $\mathrm{C}$ respectively. The results show significant difference between the three groups in their general level of reading comprehension at the end of the study. Meanwhile, to ensure true difference of the participants' reading comprehension competency ( $\mathrm{N}=47$ ), One-way Analysis of Variance (ANOVA) was conducted.

TABLE IV.

RESULTS OF ONE-WAY ANALYSIS OF VARIANCE (ANOVA) OF POSTTEST

\begin{tabular}{l|l|l|l|l}
\multicolumn{1}{l|}{ ANOVA } & Sum of Squares & df & Mean Square & F \\
\hline Between Groups & 100.820 & 2 & 50.410 & 21.931 \\
Within Groups & 101.137 & 44 & 2.299 & .000 \\
Total & 201.957 & 46 & & \\
\hline
\end{tabular}

A one way between-groups analysis of variance was conducted to explore the reading comprehension competency of participants at the end of the study as measured by Reading Posttest. The participants were divided into three groups randomly. There was statistically significant difference at the $p<.05$ level in Reading Posttest scores for the three groups: $F(2,44)=21.931, p=.000$. The effect size, calculated using eta squared, was .49 . This size effect indicated that the actual difference in mean score between groups was quite large.

TABLE V.

RESULTS OF POST HOC TEST FOR POSTTEST

\begin{tabular}{|c|c|c|c|c|c|c|c|c|c|}
\hline \multicolumn{10}{|c|}{ Post Hoc Tests } \\
\hline & \multirow[t]{2}{*}{ (I) Groups } & & \multirow[t]{2}{*}{ (J) Groups } & & \multirow{2}{*}{$\begin{array}{l}\text { Mean Difference } \\
(\mathrm{I}-\mathrm{J})\end{array}$} & \multirow[t]{2}{*}{ Std. Error } & \multirow[t]{2}{*}{ Sig. } & \multicolumn{2}{|c|}{$95 \%$ Confidence Interval } \\
\hline & & & & & & & & $\begin{array}{l}\text { Lower } \\
\text { Bound }\end{array}$ & $\begin{array}{l}\text { Upper } \\
\text { Bound }\end{array}$ \\
\hline \multirow[t]{6}{*}{ LSD } & Dimension 2 & Group A & dimension3 & Group B & $-1.867^{*}$ & .554 & .002 & -2.98 & -.75 \\
\hline & & & & Group C & $1.690^{*}$ & .537 & .003 & .61 & 2.77 \\
\hline & & Group B & dimension3 & Group A & $1.867^{*}$ & .554 & .002 & .75 & 2.98 \\
\hline & & & & Group C & $3.557^{*}$ & .537 & .000 & 2.47 & 4.64 \\
\hline & & Group C & dimension3 & Group A & $-1.690^{*}$ & .537 & .003 & -2.77 & -.61 \\
\hline & & & & Group B & $-3.557^{*}$ & .537 & .000 & -4.64 & -2.47 \\
\hline
\end{tabular}

*. The mean difference is significant at the 0.05 level.

The results of one way ANOVA showed the significant of treatments in groups. However, to determine the difference between groups Post Hoc Test was conducted. Post-hoc comparisons using the Tukey HSD test indicated the mean score for group A was significantly different from group B and group C. Based on the results of Post-hoc 
comparisons, employing past-task activities in the classrooms have significant impacts on EFL learners' reading achievements.

\section{B. Qualitative Data Analysis}

The qualitative data was gathered through semi-structured interviews with five learners who participated in this study. The procedure for analyzing qualitative data was as follows: Each data set was read several times to gain some sense of the main ideas being expressed. Then the data was coded and analyzed manually and subjectively.

There are some important points in interviews that are presented here:

- As students can monitor their own progress in a task-based instruction, especially post-task activities, they had a positive attitude toward employing post-task activities in language classrooms. Mohammad said in his interview: "when we repeat a task in the classroom, we can detect our mistakes and try to obviate them in the future and I believe that practice makes perfect."

- Students mentioned repeatedly in their interview that task-based instruction provides a remarkable opportunity for them to check their classmates' performance. Peer feedback has a positive impact on students' attitudes. Mohammad and Parham are classmates. They said in their interview that they learn best when they correct their friends. "I like it very much when Mohammad discovers my mistakes". (Parham said in his interview)

- Most students show strong motivation to participate in such kinds of language classrooms. "In my opinion, doing tasks in the class change its atmosphere. Students learn the points in a friendly environment. I think all students like to participate in this classroom. In my previous class, only our teacher gave us information about the lesson and we had no role in the class. The teacher was a knowledgeable teacher but we don't [didn't] like the class atmosphere". (Meysam stated in his interview)

- Lack of confidence was the main obstacle for students to participate in the educational tasks. "Before this course, we largely relied on our teacher ability. The most stressful time of the class was when the teacher asked some questions or took quiz. But in this course, we should rely on our own and our classmate ability. Of course, it is an effective way of language teaching, but I think I am not ready to participate in these tasks voluntarily". (Reza claimed in his interview)

The results of both quantitative and qualitative data indicate that conducting task-based instruction with focusing on post-task activities enhance students' ability to monitor their progress effectively. They can also take advantage of peer feedback that would be a praiseworthy feature of every task-based instruction. They also stated that individual differences can be a determining factor in learners' engagement in classroom tasks. This finding is confirmed with what Mellati, et al. (2015) who stated that individual factors such as learners' anxiety have significant impacts on learners' participation in classroom activities.

The findings of present study are in confirmed with Ellis (2009) who states that post-task activities provide great opportunities for repeating a task; persuade learners to reflect on how the task was performed; and foster their attention to language form, especially those language forms that learners had problem with them when they wanted to perform a task. The results also are consistent with Mozgalina (2015) who explains that task-based instruction motivates language learners to engage in classroom activities that lead into their satisfaction at the end of the course. Just like Nikula (2015) and Llinares and Dalton-Puffer (2015), the present study demonstrated that repeated performance enhances learners' proficiency. The results of interview also demonstrated that noticing post-task activities in the classroom increase learners' motivation and self-confidence to participate in the task and change their attitudes about language learning. Generally, there is a consensus among teachers and researchers that task-based instruction is an effective and useful method for teaching language; however, attention to post-task activities has at least three advantages for language learners. According to the results of interviews: 1) Post-task activities shed light on learners' strengths and weaknesses especially in the repeated performance. They understand what they learned and what not. Learners can promote their strengths by practice and obviate their weaknesses by efficient learning strategies. 2) Post-task activities increase learners' motivation to participate in classroom activities. There is a general agreement in the literature that motivation plays an integral role in successful learning. Motivation is one of the most frequently used words in psychology. It refers to what drives a person into doing something and has two types: intrinsic and extrinsic. To a large extent, everything that we perform is because of at least two important reasons: the first one is a reward and the second one is a consequence of not doing something. These two reasons can be obvious tangible benefits as Pae (2008) stated can be a financial reward; enjoyment; or the risk of these being taken away through losing one's job. Here, knowing about their strengths and weaknesses are good potential reasons to boost learners' intrinsic motivation. 3) Post-task activities have significant impact on learners' positive attitudes about learning context, teacher, peers, and material. In a task-based instruction that is followed by post-task activities, learners understand clearly what they learned and they need to learn. Obviously, this point changes their attitudes about that language class. They follow the instruction precisely as they know the lesson plan and its possible results evidently. In sum, contrary to the Lyster (2014) who stated that task-based instruction is not as significant as mentioned in the literature, the findings of present study demonstrated that post-task activities enhance learner' language proficiency. The findings also are consistent with Lynch and McLean (2001), García Mayo (2007), and Samuda and Bygate (2008) who claimed repetition of a task will increase its effectiveness and consequently the language level to complete that task. They believe that when language learners do a task again their language production and their results will be improved, for instance, they will be able to use more complex expressions, to transfer their intended meaning more clearly, and finally they will be able to use language more fluently. 


\section{CONCLUSIONS}

The present study investigated the effects of task-based instruction and post-task activities such as asking comprehension question, reflection on task, and repeated performance on EFL learners' reading achievements. The results of both quantitative and qualitative data demonstrated that task-based instruction and post-task activates have a significant effect on learners' language ability and language proficiency. Post-task activities provide a remarkable opportunity for learners to monitor their own progress and enhance their language ability by focusing on peer feedback. The results of interview indicated that learners are strongly motivated to participate in such programs. The findings demonstrated that post-task activities are as important as pre-task and during-task activities. However, lack of selfconfidence is the main obstacle in these kinds of language classrooms. The findings provide adequate guidelines for policy makers, stakeholders, and teachers for planning more effective teaching and learning contexts. They should consider post-task activities in their lesson plans. Learners' characteristics and individual differences also should be noticed in a task-based instruction. Furthermore, more studies are required to focus on different phases (pre-task, during task, and post-task) of a task-based instruction exclusively. Considering contextual factors on task-based instruction will

lead researchers into new facts about effective learner-teacher relationship and adequate language teaching environment.

\section{REFERENCES}

[1] Ajideh, P. (2003). Schema theory-based pre-reading tasks: A neglected essential in the ESL reading class. The Reading Matrix 3-1, 1-14.

[2] Asgarikia, P. (2014). The effects of task type, strategic planning and no planning on written performance of Iranian intermediate EFL learners. Procedia - Social and Behavioral Sciences 98, 276-285. doi: 10.1016/j.sbspro.2014.03.417.

[3] Bagher Shabani, M. \& Ghasemi, A. (2014). The effect of task-based language teaching (TBLT) and content-based language teaching (CBLT) on the Iranian intermediate ESP learners' reading comprehension. Procedia - Social and Behavioral Sciences 98, 1713-1721. doi: 10.1016/j.sbspro.2014.03.598.

[4] Bao, G. (2015). Task type effects on English as a foreign language learners' acquisition of receptive and productive vocabulary knowledge. System 53, 84-95. http://dx.doi.org/10.1016/j.system.2015.07.006.

[5] Brabander, C. J. \& Martens, R. L. (2014). Towards a unified theory of task-specific motivation. Educational Research Review 11, 27-44. http://dx.doi.org/10.1016/j.edurev.2013.11.001.

[6] Bygate, M., Skehan, P., \& Swain, M. (2001). Researching pedagogic tasks, second language learning, teaching and testing. UK: Longman.

[7] Derwing, T., Rossiter, M., Munro, M., \& Thomson, R. (2004). Second language fluency: Judgments on different tasks. Language Learning 54, 655-679.

[8] Ellis, R. (2001). Frequency effects in language processing: A review with implications for theories of implicit and explicit language acquisition. Studies in Second Language Acquisition 24, 143-188.

[9] Ellis, R. (2009). Task-based language teaching: Sorting out the misunderstandings. International Journal of Applied Linguistics $19.3,221-245$.

[10] Finch, A. (2006). Task-based supplementation: Achieving high school textbook goals through form-focused interaction. English Teaching 61.1, 1-26.

[11] García Mayo, M. (2007). Investigating tasks in formal language learning. Multilingual Matters Ltd: Canada.

[12] Geng, X. \& Ferguson, G. (2013). Strategic planning in task-based language teaching: The effects of participatory structure and task type. System 41, 982-993. http://dx.doi.org/10.1016/j.system.2013.09.005.

[13] Hei, M., Strijbos, J. V., Sjoer, E., \& Admiraal, V. (2016). Thematic review of approaches to design group learning activities in higher education: The development of a comprehensive framework. Educational Research Review 18, 33-45. http://dx.doi.org/10.1016/j.edurev.2016.01.001.

[14] Huang, S., Eslami, Z., \& Willson, V. (2012). The effects of task involvement load on L2 incidental vocabulary learning: A meta-analytic study. The Modern Language Journal 96.4, 544-557. DOI: 10.1111/j.1540-4781.2012.01394.x.

[15] Khademi, M., Mellati, M., \& Etela, P. (2014). Strategy-based instruction: Explicit strategy training and Iranian EFL learners' test performance. International Journal of English Language and Literature Studies 3.4, 356-368.

[16] Khodabakhshzadeh, H. \& Mousavi, B.B.S. (2012). The effect of different types of repeated performance (private vs public) as post-task activities on the English students' accuracy and fluency in L2 oral production. I.J.Modern Education and Computer Science, 5, 53-62. DOI: 10.5815/ijmecs.2012.05.08.

[17] Kim, Y. \& Tracy-Ventura, N. (2013). The role of task repetition in L2 performance development: What needs to be repeated during task-based interaction?. System 41, 829-840. http://dx.doi.org/10.1016/j.system.2013.08.005.

[18] Laufer, B. \& Hulstijn, J. (2001). Incidental vocabulary acquisition in a second language: The construct of task-induced involvement. Applied Linguistics 22.1, 1-26.

[19] Lee, S. O. (2011). Using post-task written vocabulary exercises in task-based instruction. Language Education in Asia 2.1, 1527.

[20] Lee \& Gunderson. (2011). Select reading: Intermediate. ( $2^{\text {nd }}$ Edition), Oxford: Oxford University Press.

[21] Lewis, M. (2002). Implementing the Lexical Approach: Putting Theory into Practice. Boston, MA: Heinle.

[22] Littlewood, W. (2007). Communicative and task-based language teaching in East Asian classrooms. Language Teaching 40.3, 243-249.

[23] Llinares, A. \& Dalton-Puffer, C. (2015). The role of different tasks in CLIL students' use of evaluative language. System 54, 69-79. http://dx.doi.org/10.1016/j.system.2015.05.001.

[24] Lynch, T. \& McLean, J. (2001). 'A case of exercising': Effects of immediate task repetition on learners' performance. In Bygate, Skehan \& Swain (Eds.). Researching pedagogic tasks, second language learning, teaching and testing. UK: Longman. 
[25] Lyster, R. (2014). Using form-focused tasks to integrate language across the immersion curriculum. System 43, 1-10. http://dx.doi.org/10.1016/j.system.2014.09.022.

[26] Ma, Q. \& Kelly, P. (2006). Computer assisted vocabulary learning: Design and evaluation. Computer Assisted Language Learning 19.1, 15 - 45. DOI: 10.1080/09588220600803998.

[27] Mcdonough, K., \& Chaikitmongkol, V. (2007). Teachers' and learners' reactions to a task-based EFL course in Thailand. TESOL Quarterly 41.1, 107-132.

[28] Mellati, M., Khademi, M., \& Etela, P. (2015). Challenges of mediation theory and gender differences in Iranian EFL contexts. Theory and Practice in Language Studies 5.8, 1664-1671. DOI: http://dx.doi.org/10.17507/tpls.0508.17.

[29] Mellati, M., Zangoei, A., \& Khademi, M. (2015). Technology integration: EFL learners' level of anxiety and their performance in writing tests. International Journal of Social Sciences \& Education, 5(2), 240-252.

[30] Motallebzadeh, K. \& Ganjali, R. (2011). SMS: Tool for L2 vocabulary retention and reading comprehension ability. Journal of Language Teaching and Research, 2(5), 1111-1115. doi:10.4304/jltr.2.5.1111-1115.

[31] Mozgalina, A. (2015). More or less choice? The influence of choice on task motivation and task engagement. System 49, 120 132. http://dx.doi.org/10.1016/j.system.2015.01.004.

[32] Najjari, R. (2014). Implementation of task-based language teaching in Iran: Theoretical and practical considerations. Procedia Social and Behavioral Sciences 98, 1307-1315. doi: 10.1016/j.sbspro.2014.03.547.

[33] Nation, I. S. P. (2001). Learning vocabulary in another language. Cambridge: Cambridge University Press.

[34] Nikula, T. (2015). Hands-on tasks in CLIL science classrooms as sites for subject-specific language use and learning. System 54, 14-27. http://dx.doi.org/10.1016/j.system.2015.04.003.

[35] Nunan, D. (2006). Task-based language teaching in the Asia context: Defining 'task'. Asian EFL Journal 8.3, 12-18.

[36] Pae, T. (2008). Second language orientation and self-determination theory: A structural analysis of factors affecting second language achievement. Journal of Language \& Social Psychology 27.1, 5-27.

[37] Prabhu, N.S., (1987). Second language pedagogy. Oxford University Press: Oxford.

[38] Ruiz-Funes, M. (2015). Exploring the potential of second/foreign language writing for language learning: The effects of task factors and learner variables. Journal of Second Language Writing 28, 1-19. http://dx.doi.org/10.1016/j.jslw.2015.02.001.

[39] Sadeghi, K. \& Sharifi, F. (2013). The effect of post-teaching activity type on vocabulary learning of elementary EFL learners. English Language Teaching 6.11, 65-76. doi:10.5539/elt.v6n11p65.

[40] Samuda, V., \& Bygate, M. (2008). Tasks in second language learning. Basingstoke, Hampshire RG21 6XS: England.

[41] Schmitt, N. \& Carter, R. (2004). Formulaic sequences in action: An introduction. In Schmitt, N. (Ed.). (2004). Formulaic sequences, pp. 1-22. Amsterdam: John Benjamins Publishing Company.

[42] Shintani, N. (2011). A comparative study of the effects of input-based and production-based instruction on vocabulary acquisition by young EFL learners. Language Teaching Research 15.2, 137-158. DOI: 10.1177/1362168810388692.

[43] Skehan P. (2009). 'A framework for the implementation of task-based instruction', In Van den Branden, K., Bygate M., and Norris J. (Eds.), Task based language teaching: A reader, Amsterdam: John Benjamins.

[44] Stylianides, A. J. \& Stylianides, G. J. (2008). Studying the classroom implementation of tasks: High-level mathematical tasks embedded in 'real-life' contexts. Teaching and Teacher Education 24, 859-875. doi:10.1016/j.tate.2007.11.015.

[45] Taylor, D.W., Berry, P.C., and Block, C.H. (1958). Does group participation when using brainstorming facilitate or inhibit creative thinking?. Administrative Science Quarterly, 3(1), 23-47.

[46] Van den Branden, K., Bygate, M., \& Norris (Eds.). (2009). Task-based language teaching: a reader. Amsterdam: Benjamins.

[47] Wang, A. Y. (2012). Exploring the relationship of creative thinking to reading and writing. Thinking Skills and Creativity 7 , 38-47. doi:10.1016/j.tsc.2011.09.001.

[48] Widdowson, H. (2003). Defining issues in English language teaching. Oxford University Press: Oxford.

Marzieh Khademi got her M. A. in TEFL from Islamic Azad University (IAU), Torbat-e-Heydarieh Branch, Iran. Currently, she is English instructor in Baqir-al-Olum University, Qom. Her areas of interest are teacher education, teacher development, strategybased instruction, and e-learning. She has published many articles in reputable international journals. She has also some other articles under publication.

Morteza Mellati is a PhD student in TEFL at Tehran University (TU), Iran. His areas of interest are teacher beliefs, teacher education, teacher development, task-based instruction, strategy-based instruction, ESP, and e-learning. He is an editorial board in Education Journal, New York, USA; International Journal of Elementary Education, New York, USA; and International Journal of Secondary Education, New York, USA; he is also a reviewer in Reading \& Writing Quarterly: Overcoming Learning Difficulties; International Journal of English Language and Literature Studies; and Education Practice and Innovation. He has published many articles in reputable international journals and conferences. He has also many other articles under publication.

Samaneh Notghi Moghaddam conducted many EFL courses at Al-Mustafa Open University. Her area of interest is task-based language teaching. 